\title{
0020. Microcirculatory perfusion and vascular reactivity are altered in post cardiac arrest patients, irrespective of target temperature management to $33^{\circ}$ vs $36^{\circ}$ (substudy TTM)
}

\author{
M Koopmans ${ }^{1 *}$, MA Kuiper ${ }^{1}$, R Endeman ${ }^{2}$, G Veenstra ${ }^{1}$, NAR Vellinga ${ }^{1}$, R Vos de ${ }^{3}$, EC Boerma \\ From ESICM LIVES 2014 \\ Barcelona, Spain. 27 September - 1 October 2014
}

\section{Introduction}

After cardiopulmonary resuscitation (CPR), following an out of hospital cardiac arrest (OHCA) hemodynamic failure is common, due to a combination of heart failure and ischemia reperfusion injury. Comatose post-cardiac arrest patients are treated on the intensive care unit (ICU) with mild therapeutic hypothermia $\left(33^{\circ}\right)$, nowadays referred to as target temperature management (TTM) for an assumed neuroprotective effect.

\section{Objectives}

In previous reports both microcirculatory alterations and impaired vascular reactivity have been described in post cardiac arrest patients treated with mild therapeutic hypothermia. As of now it is unknown whether these alterations are related to the temperature management itself. Aim of the present study was to investigate the potential difference in microcirculatory alterations and vascular reactivity in patients after out of hospital cardiac arrest treated with target temperature management of $33^{\circ} \mathrm{C}$ (TTM33) in comparising to patients treated with $36^{\circ} \mathrm{C}$ (TTM36).

\section{Methods}

Our study was designed as a a priory substudy of the open label randomized controlled TTM trial in 2 Dutch mixed ICU's. Microvascular flow index (MFI) was assessed by Side Stream Darkfield imaging and vascular reactivity by near infrared spectroscopy. Variables, including systemic

${ }^{1}$ Medical Center Leeuwarden, Intensive Care, Leeuwarden, Netherlands Full list of author information is available at the end of the article haemodynamics were recorded at start study (T1), after 12 hours (T2) and after 24 hours (T3).

\section{Results}

22 patients were included, 13 in TTM33 and 9 in TTM36. At T1 MFI between groups did not differ significantly (1.08[0.4-1.9] versus $1.67[0.7-2.4]$ respectively, $\mathrm{p}=0.59)$. The difference between groups remained insignificant over time. At $\mathrm{T} 1$ tissue oxygenation $(\mathrm{StO} 2)$ was significantly lower in TTM36 in comparison to TTM33 (58.9 \pm 13.5 versus $44.6 \pm 15.8, \mathrm{p}=0.03)$. Over time this difference between groups disappeared. However, vascular reactivity, expressed as the descending and ascending slope of StO2 after a standardized ischemic occlusion test was similar between groups

\section{Conclusions}

In this relatively small sample size study microcirculatory blood flow and vascular reactivity did not change between TTM33 and TTM36

Clinicaltrials.gov nr. NCT01850485

\begin{abstract}
Authors' details
${ }^{1}$ Medical Center Leeuwarden, Intensive Care, Leeuwarden, Netherlands. ${ }^{2}$ Onze Lieve Vrouwe Gasthuis, Intensive Care, Amsterdam, Netherlands. ${ }^{3}$ Academic Medical Center, Epidemiologic, Biostatistics and Bioinformatics, Amsterdam, Netherlands.
\end{abstract}

Published: 26 September 2014

\section{References}

1. Nielsen $\mathrm{N}$, et al: TTM Trial Investigators. Targeted Temperature Management at $33 \mathrm{C}$ versus $36 \mathrm{C}$ after cardiac arrest. The New England Journal of Medicine 2013, 369(23):2197-206.

\section{SpringerOpen ${ }^{\odot}$}

๑ 2014 Koopmans et al; licensee Springer. This is an Open Access article distributed under the terms of the Creative Commons Attribution License (http://creativecommons.org/licenses/by/2.0), which permits unrestricted use, distribution, and reproduction in any medium, provided the original work is properly cited. 
2. Sakr $\mathrm{Y}$, et al: Persistent microcirculatory alterations are associated with organ failure and death in patients with septic shock. Crit Care Med 2004, 32(9):1825-1831.

3. Fries $\mathrm{M}$, et al: Microvascular blood flow during cardiopulmonary resuscitation is predictive of outcome. Resuscitation 2006, 71:248.

doi:10.1186/2197-425X-2-S1-01

Cite this article as: Koopmans et al:: 0020. Microcirculatory perfusion and vascular reactivity are altered in post cardiac arrest patients,

irrespective of target temperature management to $33^{\circ}$ vs $36^{\circ}$ (substudy TTM). Intensive Care Medicine Experimental 2014 2(Suppl 1):01.

\section{Submit your manuscript to a SpringerOpen ${ }^{\circ}$ journal and benefit from:}

- Convenient online submission

- Rigorous peer review

- Immediate publication on acceptance

- Open access: articles freely available online

- High visibility within the field

- Retaining the copyright to your article

Submit your next manuscript at $\gg$ springeropen.com 